\title{
THE LONELINESS OF TWO LONG-DISTANCE RATIONALISTS: GELLNER AND BASSANI ${ }^{*}$
}

\author{
WILHELM SNYMAN \\ (University of Cape Town)
}

\section{Sommario}

Questo articolo è un'indagine di quanto gli scritti del noto sociologo, antropologo, storico e filosofo Ernest Gellner (1925-1995) si prestino come strumento critico per $i$ testi letterari in genere, e due testi di Giorgio Bassani (1916-2000) in particolare: Gli occhiali d'oro e II giardino dei Finzi-Contini.

Ernest Gellner had too many ideas for us to go into too much depth here. In his last book, Language and Solitude, the central theme in the first half of his work is a discussion of the battle between what he terms "rationalistic individualism" and "romantic communalism". He sees these two rival notions as pivotal in trying to understand modernity. He views the appeal of Gesellschaft (Society), i.e. a situation that enshrines the individual and his or her rights and responsibilities and Gemeinschaft

L'articolo è stato presentato come seminario alle università di Edimburgo e Oxford il 5 e 9 marzo 2009 rispettivamente. 
(Community), i.e. a situation that enshrines the rights and responsibilities of the community before that of the individual as oppositional:

There are two fundamental theories of knowledge. These two theories stand in stark contrast to each other. They are profoundly opposed. They represent two poles of looking, not merely at knowledge, but at human life. (1998:3)

By this he is referring to another, more abstract definition of these terms, namely the "atomistic" and the "organic" views of the world. We may find these ideas old hat; we may agree or disagree or find a host of reasons why his view of the world may be considered absurdly reductive, or even far too simplistic, but a starting point it certainly is as a way of trying to unravel the world we live in and how it has come to be what it is. The question that intrigues is: can such a view of the world find application to a literary text, and if so which texts are best suited to what has been called a Gellnerian vision? As a student of comparative literature, it behoves one to look at how seemingly unrelated disciplines can shed light on a literary text. To do so may appear contrived, stilted - surely a text can speak for itself if it is worthwhile?

Anna Karenina is still a good read without cluttering it with jargon. But it is thanks to novels such as this and many others, let's say about $19^{\text {th }}$ century Russia, that we have some idea of what life was like in those times. The same applies for Ivan Turgenev, or for Fascist Italy Ignazio Silone, or Louisa May Alcott or Mark Twain or J.M. Coetzee. They can be seen as windows on a particular society at a given time. As soon as we dip into that way of thinking we then think, well maybe an idiosyncratic thinker such as Ernest Gellner might be useful beyond his professed disciplines of philosophy, social anthropology, and history as a way of 
looking at literature. After all, don't novels also shed light on philosophy, social anthropology and history? Literature is not a one-way street ${ }^{1}$.

So why Bassani? What one is endeavouring to do is to experiment, as if to say, let's look over the fence of literary theory, or national literatures and start digging and see what we can find. This has been done before. All one is doing now is to see to what extent, if at all, Gellner can help us to illuminate a text such as Gli occhiali d'oro or Il giardino dei FinziContini, - henceforth referred to as Gli occhiali and Il giardino for brevity's sake - the one a novella, the other a fully fleshed novel of Tolstoyan proportions.

Ernest Gellner was arguably one of the more controversial thinkers of his age, praised and often condemned for views that went against the current of many a received wisdom of his time. He was a philosopher, sociologist, anthropologist and an historian. He is best known for his works such as Book, Plough and Sword, Words and Things, Legitimation of Belief, Language and Solitude, not to mention possibly his best known text, Nations and Nationalism.

To briefly introduce Gellner's works, suffice it to say that they are steeped in a deep understanding of the effects of historical forces, historical forces that he was often fated to live through. Born in Paris, he grew up in Czechoslovakia, and we can all imagine the intimate experience he had of the ideological whirlwinds that held sway in Europe during his lifetime.

To understand Gellner in the broadest terms, the introductory note of his Postmodernism, Reason and Religion should be read:

See M. Hanne, The Power of the Story - Fiction and Political Change, Oxford, Berghahn Books, 1996:34 et seq. 
On questions of faith, Ernest Gellner believes, three ideological options are open to us today. One is a return to a genuine and firm faith in a religious tradition. The other is a form of relativism which abandons the notion of unique truth altogether, and resigns itself to treating truth as relative to the society of culture in question. The third, which Gellner calls enlightenment rationalism, upholds the idea that there is a unique truth, but denies that any society can ever possess it definitively. (Introduction to Postmodernism, Reason and Religion, 1992:i)

This third option is the most compelling when looking at Bassani, (who died relatively recently in 2000).

The question is not whether we agree with everything Gellner has to say, when he speaks as a social anthropologist, or anything he has to say for that matter about the rise of modernity, Reason or the rise of individuality, but rather whether his modus operandi, the questions he asks and the way he asks them that can be of use to us in analysis specific literary texts.

While Gellner had a lot to say about how societies came about, how the coming into being of modernity was not inevitable, the aspect one is concentrating on is his vision of individualism and what has been described as his Rationalist Fundamentalism². Predictably, Gellner abhorred what he considered "closed systems" and was a champion of the "liberal polity".

Gellner laid great stress on the rise of individualism as a sine qua non of modernity and on ideas of truth and knowledge, which led him to the conclusion that the search for truth is essentially a solitary activity. Of

2 M. Buchowski, "The Social Condition of Knowledge: Gellner and the Postmodernist Menace" in Social Evolution and History, Summer 2003, Volume 2, Number 2:34-54. 
course, the nigh naïve idea of "searching for truth" is anthropocentric, but the introduction to Postmodernism, Reason and Religion specifically says "On questions of faith", and in a sense that is what we're dealing with here. The faith that we might be able to discern some elements that give us a better understanding of the world - and in our case, a closer understanding of some literary texts. By way of summary one should add that Gellner maintains that humanity progressed through what he saw as the three stages of human development, namely hunter-gatherer to agraria to industria. This was Gellner's way of trying to understand the emergence of the modern world as we have it today. And he was not alone in this approach, but cardinal to his thinking is that while the industrial age emerged out of the Enlightenment, in doing so created a world - that in having separated the social, religious and the political - devoid of comfort, solace or meaning.

The "cosy habitat" as he terms it, is not to be found in a world where the institutions of state, economics, religion and family have been so thoroughly separated.

While many critics have discussed the limitations of Gellner's view, presented here inevitably in a reductive fashion, the main criticism is that his "Trinitarian" (hunter-gather-agraria-industria) view is too limiting and excludes the unpredictable as well as those elements which arise out of history spontaneously. We get closer to our goal of understanding Bassani when Gellner says:

Above all, society never constitutes an authority or a vindication. If society itself, or some institution within it, makes such a claim, then that is a usurpation and to be strenuously resisted. Society has no right to impose its authority either on inquiry or on its outcome. Neither its views, nor its outcome is authoritative. Truth stands outside 
and above, it cannot be under social or political control. Legitimation of ideas by authority, by consensus, or the social creation of truth, is an abomination. (1998:3)

In Gli occhiali, we see how - as per Gellner - the gradual invasion of the state's version of the truth makes inroads into, and ultimately determines personal lives. The state ceases to be an abstract concept and the author consciously, layer by layer, peels away the elements that divide the personal from the political, and ultimately the personal becomes political. We witness in Gli occhiali the coming of age of our protagonist, his moral consciousness develops and he is faced with choices between right and wrong, between acquiescing and compromising with the state, as his father does in Il giardino, or taking a stance that puts him in a precarious position, but ultimately exemplifies his defiance and freedom, both artistically and as an individual.

It is Gellner's notion of individuality and the emergence of cognition, i.e. the emancipation from the religious or the transcendental, on an anthropological level, that coincides with Bassani's io narrante protagonist who becomes aware of what he is, morally, socially, politically and how these express themselves in ethical terms. We are moving to the creation of what, in Gellner's terms, is the "atomistic" individual.

The various strands of cognition, of social, political, historical awareness further manifest themselves in Bassani's use of language and his use of language as a transmitter of knowledge. Bassani's language reinforces the idea of language as a way of reinforcing continuity, amidst a situation in which continuity is imperilled. In effect, we are dealing with a situation where continuity cannot be taken for granted and the artistic expression thus becomes the guarantor of continuity, where continuity can 
no longer to be relied upon as in the case of the Jewish community of Ferrara that feels its institutions under threat. Continuity of the community can no longer be guaranteed under Fascism, no matter what compromises the community makes with the regime. Thus it comes as no surprise that Bassani introduces Il giardino thus:

La tomba era grande, massiccia, proprio imponente: una specie di tempio, tra l'antico e l'orientale, come se ne vedeva nelle scenografie dell'Ä̈da e del Nabucco in voga nei nostri teatri d'opera fino a pochi anni fa. (1985:13)

[The tomb was huge, solid and truly imposing, a kind of temple, something of a cross between the antique and the oriental, such as might be encountered in those stage sets of Aïda or Nabucco very much in vogue at our theatres only a few years back.] (McKendrick, 2007:7)

The above quote illustrates the millennial views that Bassani also maintains, as if to relativise, diminuify the moment of history in which his tale in Il giardino unfolds. Moreover, significant too are the names of the Verdi operas with their Risorgimento and Old Testament echoes. Bassani seems to share with Gellner that legitimation of ideas by secular authority, by consensus, or the social creation of truth, is an abomination (Gellner: 1998) in that the state that was imposing its truth on society was itself an abomination, one that he could not identify with, even before the adoption of the Race Laws of 1938. (The inherent risk of the individual delegating to the state the responsibility for one's own life is self-evident, but reflects the eternal dilemma of the relationship between the individual and the collective, between the individual and society). The emphasis on language and its function as a tool for continuity has been noted by many critics: 
"The very act of naming objects defeats their death through the strong emotions that the "words" awaken" (Radcliff-Umstead, 1985:116-125).

Words then, in the context of shifting values and a precarious ethical universe form part of a death-defying ritual, as a consequence of death's immanence and omnipresence. Words in effect become part of what Gellner calls the "cosy habitat"; they are used to reflect the retreat into a world that continues to make sense, or at least reflect an attempt to make sense of the world, futile though doing so may appear to be. The "cosy habitat" is a term Gellner uses to describe the "organic" vision, the sense of community. In the case of Bassani we're dealing with the recreation of an ephemeral cosy habitat, a return to the organic of sorts, the atomist returning to the organic, in the full knowledge that his "organic" realm is under threat from a rival organic view of the world, namely Fascism and the Race Laws.

Inasmuch as language is a transmitter of values and knowledge, in Bassani language not only echoes and reinforces a notion of continuity but becomes a device all the more valuable because of the precariousness of the times. In this regard Patrick Heady summarises Gellner's observations about kinship and language:

[...] The first component of the ideal language would be a system of labelling each individual's relations to his or her ancestors so precisely that for any two members of the society it would become instantly clear from these labels (Gellner refers to them as 'names') what, if anything, the biological relationship between two individuals was.... Gellner compares these 'names' to coordinate references in physical space. They would make it possible to identify one aspect of the kinship relationship between (physical) descent and marriage (reproductive partnership). (2003:75-87) 
We can clearly see in Bassani's novels how his descriptions of Ferrara are used to this end. Radcliffe-Umstead goes further and puts it more succinctly when he says:

The cluttered collection of opalines, like the beloved objects cited in the verses of the "twilight" poets, [I crepuscolari], represents the objective correlative about which both the narrator and the character Micòl summon forth images of the cosy comfort and traditional elegance of the young woman's apartment" (Radcliff-Umstead: 1985). The very act of naming objects defeats their death through the strong emotions that the "words" awaken. (1985:116-125)

In Bassani then, legitimation and continuity are conferred through the frequent and accurate references to spaces, moods, attitudes, time and objects, certainly not through the social creation of truth, i.e. Fascism or the state. We can see where Occhiali d'oro fits in on a Gellner's scheme: Bassani's io narrante would seem to embody the values of the Enlightenment as well as those of the Risorgimento, a patriotism of a liberal and democratic hue. In the novel the only would-be "cosy habitat" on a large scale is represented by Fascism, a "cosy habitat" that purported to provide solace for a nation from the rigours and falsehoods of modernity, only to replace it with another set of falsehoods. But on a more intimate level, the io narrante seeks also his "cosy habitat" in the selfconscious knowledge that he is part of something more ancient than the transitory phenomenon of Fascism. His culture and religion, secular and Sephardic, have provided him as well with a set of values that he can seek and find solace; the tragic irony being that the source of his solace is also what condemns him in that fraught period in history. 
Let's consider again Gellner's statement, from the last book he wrote, Language \& Solitude 2 where he says right from the start:

There are two fundamental theories of knowledge. These two theories stand in stark contrast to each other. They are profoundly opposed. They represent two poles of looking, not merely at knowledge, but at human life. Aligned with these two polar views of knowledge, there are also related, and similarly contrasted, theories of society, of man, of everything. This chasm cuts right across our total social landscape. (1998:3)

This is how Gellner refers to the chasm between the "atomistic" view of the world and the "organic" view of the world. This is significant because knowledge, whether arrived at by ritual, observation or intuition, take on many forms and functions:

What counts as "a philosopher" differs far more from country to country. Or even within them, than is the case for any another "subject". Societies and cultures which do not differ radically in other respects, display extreme differences at this point, which would seem to suggest that the shared intellectual or social situation of our time does not of itself impose any single solution on us. (1979:14)

Gli occhiali d'oro then in particular serves as a kind of crucible revealing the historical, philosophical and social anthropological elements at work in a given society. The novel ceases to be merely one about two outcasts, a homosexual and a Jew, finding each other and coming to some epiphany about the role of the individual in society. Gellner in this sense helps us to see that the novel has a resonance way beyond the immediate narrative. 
We might know this already, be aware of the resonance the novel has without appealing to Gellner, but he gives us a useful vocabulary, a kind of ladder with which to look over the fence and articulate in other ways what we may already know through other theories or ways of looking at a text, or simply through a general knowledge of history.

Our protagonist becomes progressively aware of the historical impasse in which he finds himself and becomes more aware of the ideals which he deems sacrosanct, but which he had hitherto taken for granted until they were challenged. Gli occhiali d'oro is at once a novel of doom and defiance, in that the protagonist makes a conscious choice not to be party to the demise; to be defiant and to bear witness to a later generation of the fate of Ferrara's Jews, to be loyal to the ideals of the Risorgimento and to be a witness to the moral fragility and hypocrisy of his fellow Ferraresi.

Significantly, Piero Pieri, quoting from Benedetto Croce's Cultura e vita morale, makes the following observation and links Bassani clearly with philosophy by making reference to Benedetto Croce:

Come Croce, anche Bassani vede nella morte degli ideali risorgimentali, a favore dei valori positivisti, i presupposti nefasti che indurranno la coscienza della nazione ad aderire al regime di Mussolini. [...] Croce ricorda non senza ironia che il positivismo è stato "l'espressione più schietta del movimento e degli interessi borghesi". (2006:81)

One of the greatest merits of Bassani's oeuvre is that it provides - as do many other novels, but arguably none so intimately - a window into what one might call the "Fascist reality". Unlike say Elio Vittorini, who relied heavily on symbolism, or Natalia Ginzburg, who was often oblique in her references to the "meta-narrative" of Fascism, in Bassani we have the steady encroachment of the meta-narrative into the realm of the personal, 
into the intimate. (Of course, this applies most aptly in the creation of the enigmatic Micól, who as we know through the works of Marilyn Schneider, De Stefanis and Radcliff-Umstead and others, how she encapsulates doom, longing and fatalism and the notion of love that cannot flourish without a sense of future.)

What is significant too is that Bassani's approach does not limit us to that particular period in Italy's history, but uses it to make observations about a universal dilemma, that of the individual vs. the collective, wherever, contrasting as he often does, the intimate with the universal, the moment in the individual's life, with the moment in a society's sense of itself. Thus, too, a linkage between him and Gellner is clear in that Bassani uses his narrative to explore patterns and underlying historical truths in a manner that echoes Gellner - they have similar preoccupations: both seek solace in a belief in Reason, in the values of the Enlightenment, and in doing so reflect a belief in a liberalism, something that has the potential to emancipate the individual from cultural or ethnic vagaries - a rationalism that is "supranational", that functions as a bulwark against ethnic exclusivism, and vagaries of ethno-centricism, or what Gellner would term against the "village green"3. Cognition, in other words. (Gellner and others explore this idea more fully when discussing the crisis of liberalism in the Habsburg Empire, for example.)

For Bassani the illusion that survival can be sought through a compromise with Fascism, with the truth generated by the state, is a survival inevitably tainted. The political and the ethical components are self-evident. Betrayal on one level, against the purer ideals of the Risorgimento, betrayal of one principle, will lead to betrayal of a host of

3 "The village green stood against the Café Central of Vienna, or so it seemed" (Gellner, 1998:34). 
others, thus making the enactment of the Race Laws of 1938 that much easier, almost inevitable:

Truth stands outside and above, it cannot be under social or political control. Legitimation of ideas by authority, by consensus, or the social creation of truth, is an abomination. This vision is atomistic as well as individualistic. It not only makes the solitary individual a foreigner in his own world, separating him from it, requiring him to assert his independence; it also makes the part sovereign over the whole. (Gellner, 1998:3-4)

We see how this view of truth, of cognition, in Gellner very much defines the io narrante in both novels. The io narrante does assert his independence, makes the "part sovereign over the whole". We could then see how the io narrante's behaviour in respect of Fadigati can be seen as one conforming to Gellner's notion of the atomistic view of knowledge in that cognition goes beyond mere self-interest. The io narrante could have courted the friendship of Deliliers, could have ingratiated himself with Deliliers, yet he recognised that Deliliers' behaviour towards Fadigati has parallels with that of the community towards Jews such as himself; and that a compromise with Deliliers, however advantageous it might seem in the short term, would ultimately be illusory and undignified. Association with Deliliers is ultimately no more than a question of buying time, of compromise, the kind of compromise we see the io narrante upbraiding his father for making with Fascism in Il giardino dei Finzi Contini.

Furthermore, the individualism of the io narrante, his independent moral ("requiring him to assert his independence") stance is accentuated by separating himself from both his fellow Jews who pretend things are not as menacing as they are, and from his non-Jewish peers, who he 
knows will buckle under the pressure of the state to behave in way that conforms to the state's notion of truth, inter alia the newly-found AntiSemitic milieu engendered by the state. Piero Pieri defines Bassani thus, in this regard, accentuating his "diversità":

La 'diversità' di Bassani parte proprio dal netto distacco nei confronti di ogni pietas ebraica, e diventa atto di razionalità storica proprio perché la Passeggiata [read Gli occhiali or Il giardino] è stata scritta dopo Buchenwald e Dachau. Quanti hanno parlato del semitismo di Bassani, non hanno considerato in modo adeguato il suo "anti-semitismo"; che non contiene la critica della razza, ma piuttosto, l'identificazione dell'ebreo con l'ala conservatrice della borghesia nazionale. Nell'antisemitismo di Bassani prevale, quindi, non la denuncia dell'ebreo come tipo, [Pieri's italics] alla maniera di Weininger, ma della sua vanità di classe... (2006:68-69)

The independent stance adopted by our io narrante, is asserted not only in respect of society in general, the spirit of his times, but also in respect of the very community, because of his adherence to which he is excluded from society at large. Marilena Renda places the emphasis as follows:

Ecco allora lo sguardo simpatetico del narratore seguire i destini dei suoi personaggi nel loro procedere verso la fine, ed evocare i traumi della storia inseguendone gli echi e trascendendone i micro-frammenti di storie personali, in un interagire incessante tra destini personali e destini collettivi. (2006:128)

We go on to see how the io narrante in Gli occhiali exemplifies what Gellner describes thus: 
We explore the world by seeing actual patterns as contingent variants of deeper factors, and these we explore by rearranging actual patterns, in real or imaginary experiments. Freedom of experiment is analogous to freedom of trade, and each leads to growth in its own sphere, and the forms of freedom and consequent growth aid each other. Each is opposed to the imposition of hallowed rules or rigidities, whether based on tradition or revelation. (1998:5)

Our io narrante becomes able through his growing awareness, to identify "variants of deeper factors". He is not content with the way the world presents itself to him. He becomes aware of his difference; he is forced to become aware of something he had taken for granted, through the nascent Anti-Semitism in his society, as exemplified by the inimitable Signora Lavezzoli. He does indeed grow in his own sphere, and he finds himself in opposition "to the imposition of hallowed rules or rigidities". Significantly Gellner adds, "whether based on tradition or revelation", in other words, whether our protagonist's awareness is fuelled by his Jewish tradition, by the political milieu, by expediency or by his own would-be independently arrived at view of the world: "[...] our real situation which involves choosing our forms of life, as best we can, and not treating them as ultimate" [italics Gellner's] (1979:34).

This aspect of how a reading of Gellner can elucidate a literary text can be viewed from a different angle when we recognise that what lies at the heart of our discussion is the nature of knowledge, how knowledge is arrived at and what vision knowledge represents and the political implications of knowledge. Or to use a word Gellner likes, "cognition". Gellner, using his usual sources of Descartes, Kant, Durkheim and Weber, surmises that rationality cannot be viewed in isolation - and as conceived 
as a way of arriving at truth - Gellner reminds us that: "Truth can be secured only by stepping outside prejudice and accumulated custom and refashioning the world. It can only be achieved by means of proudly, independent, solitary Reason. We pursue it rationally, and we do it alone" (1992:8).

This is obviously a very contestable statement, if not joyously naïve, but the important point that he makes is that this truth is arrived at "alone", is a solitary exercise, very much in the way the protagonists experience this in Bassani's novels. Bassani's protagonist in Gli occhiali, while other factors force him into an acknowledgement of certain truths, his cognition is such that he responds independently to the forces being enacted around him and on him; he doesn't follow the herd, not even his own Jewish herd, he acknowledges the painful truth of his situation to himself. As we mentioned in the beginning: "enlightenment rationalism, upholds the idea that there is a unique truth, but denies that any society can ever possess it definitively" (Introduction to Postmodernism, Reason and Religion, 1992). The io narrante in Gli occhiali arrives at such a truth and embraces it in all its pain and precariousness.

If we can agree - for the moment - that Reason is the realm of the solitary individual, then there would again seem to be a confluence of Bassani and Gellner's thinking.

It takes a long time before, if ever, Reason becomes a collective asset, and when it does, it can be undermined by social and political forces and used for social or political ends. It can end buttressing any one of a number of "closed systems" against which Gellner often inveighed. This theme of "the collective" and "the solitary" recurs as we know in much of Gellner's writing, as he questions the degree to which either is tenable. One can see the roots of his anthropological thinking also in the space he devotes in much of his writing to ritual and how these and other 
manifestations of the collective help to bring about a conceptual conformity. In Bassani this is very much what we are confronted with, the collective and the individual at variance with a collective, someone who is "stepping outside prejudice and accumulated custom and refashioning the world". And he does so "alone".

What is more, is that our io narrante in Gli occhiali is obviously not entirely independent and is in effect dealing in effect with multiple collectives, or at least two, that of the Fascist state and that of religion. Gellner says for example, citing Durkheim: "[...] the ritual then imprints the required shared ideas, the collective representations, on this malleable proto-social human matter. It thereby makes it concept bound, constrained and socially clubbable" (1992:36). In other words, our io narrante in both novels is at once forged by his environment and through the situation he faces, emerges cognisant of the ethical dimension of his life and the choices he is faced with.

Radcliff-Umstead points out that language itself becomes part of the signifier of a collective, of a ritual, of a defence mechanism against an intrusive and uncomprehending society. While Radcliff-Umstead makes the observation specifically with reference to Il giardino dei Finzi Contini, it applies in comparable measure to Gli occhiali d'oro. Frequent use of dialect, and of a frame of reference that is deemed to be understandable to only to those familiar with Ferrara and its locales and street names. All of this adds to a sense of enclosure, to a sense of exclusivity and a knowledge that being understood fully is only possible to those who have lived through those times and in that milieu. However, Bassani evokes a particular era and mood so intimately, that his works acquire their universality and are accessible to us who didn't live in Ferrara in 1938 or 1943, for example. What Gellner calls here the "imprint of shared ideas", "the collective representations" and what is "socially clubbable" all 
pertain to Bassani's world - Ferrara becomes a collective representation, the "shared ideas" are the more liberal Risorgimento values and the "socially clubbable" is the adherence to the Jewish community of Ferrara, or the adherence to a set of values that resist the Fascist state. In short, we are dealing with a set of people who see themselves as free thinkers, who aspire to be at say at the apex of modernity, who see themselves as cognitively free individuals yet bound by an ancient religious tradition threatened by retrogressive forces that seek a return to a society that suppresses cognitive freedom and seeks to make them subservient to a transient totalitarianism. In short, they see themselves in opposition to the rebellion against liberal modernity. Gellner makes reference to Durkheim's assertion that "[...] in religion, society unwittingly worships itself, par divinités interposes" (1992: 37).

Bassani's Ferrara is a microcosm, intentionally, of exactly that, with the added problem that there are competing forces that demand allegiance, namely the Jewish religion, the Catholicism of the majority and the Fascist state. Before the war, with Catholicism and Fascism in a tenuous political alliance of sorts, it only leaves the Jews and the secular, nonfascist elements of society in a situation of open antagonism with the state. If we substitute the word religion with Fascism, the situation Gellner describes becomes even clearer, the state encouraging society to worship itself, in a kind of national narcissism as long as it is controlled by the state, clearly a situation antithetical to the aspirations of those who see themselves as free thinkers imbued with the spirit of rationality. And it is through these rapids that our io narrante has to navigate, has to distil his own moral order, amid all the forces vying for his allegiance. Gellner goes on to say: 
[...] but it is far less interesting and important than the view that what makes us human and social is our capacity to be constrained by compulsive concepts, and the theory that the compulsion is instilled by ritual, and that ritual is the core of religion. In this sense it was religion, and religion alone, that made us human. I do not know whether this theory is true, and I doubt whether anyone else knows either: but the question to which it offers an answer is a very real and serious one. No better theory is available to answer it. No other theory highlights the problem so well... Collective rituals inculcate shared compulsions thereby quite literally humanizing us. We cooperate because we think alike, and we think alike thanks to ritual. Durkeim's version of the Social Contract has the merit of not being circular. It does not assume rationality and social obligation among those who set up the social order. It shows how those who lack either can be induced to acquire it. In this way, rituals make society possible, and in this way, they also make us human. This is the core of Durkheim's theory. (1992:37)

Whether we agree with Durkheim, or Gellner's reading of Durkheim, is less at issue than their applicability to the situation our io narrante finds himself in either Il giardino or Gli occhiali.

We see how in Bassani that social contract is disrupted and undermined and how intimately the manifestations of rupture impinge upon his characters. Hence, as mentioned before we see how the sanctity of objects, those death defying extensions of ritual are nurtured in the Finzi-Contini household; The collective rituals, especially the Jewish ones referred to in Il giardino, form what Venturi calls "la modernità nella 
continuità"4. In a sense Venturi has captured the essence of the Bassani text: ritual thus forms part of a mechanism to cope with and to navigate through the troubled and anguished times the io narrante has to face, times that require him to rely on a faith in Reason, on a truth that is arrived at independently by applying rational, empirical faculties, not subservient to autocracy or unexamined ritual.

Also arising out of this search for truth is a defiance in Bassani, as many writers have pointed out. One could even say that as far as Gli occhiali is concerned arguably the epiphany of the novel is when the io narrante says, speaking of Fadigati: "Anziché associarmi a chi lo tradiva e lo sfruttava, avevo saputo resistere, conservargli un minimo di rispetto" (1980:71). This is a crucial sentence in the novel because it marks the triumph of the individual asserting a moral authority, to himself, in defiance of the ritualised norms of the state, but not insensible to the tenets of his predominantly secularly ethical upbringing. The sentence represents that very continuity in modernity, of an ethical view of the world, that in turn relies on ritual, transmitted knowledge and language, themes keen to Gellner's investigations. The ontological implications are even more succinctly captured when Fadigati says to the io narrante: "Accettare di essere quello che sono? O meglio adattarsi ad essere quello che gli altri vogliono che io sia?" (1980:100).

What we see here is in effect someone addressing the implications of their existence in a given situation, and the demands this makes on cognition, their sense of self, rendered all the more poignant in that coming to terms the full implications of existence cannot but lead to a profound sense of despair. It is this despair, articulated by Fadigati, that

G. Venturi, "Dimenticare Euridice" in Ritorno al Giardino - Una Giornata di Studi per Giorgio Bassani, eds. A. Dolfi \& G. Venturi, Rome, Bulzoni Editore, 2006. 
the io narrante refutes, and which shapes his defiance. He will not be party to his own destruction. His fellow Ferraresi are not confronted by the same choices, choosing instead conformity to adversity. It is in this sense that the io narrante in Gli occhiali can be viewed as a type of icon of modernity, of the atomistic view of the world, "the loneliness of the long-distance rationalist".

The io narrante wants to be what he is, what he feels he has a right to be and that includes adherence to the proud history of his Jewish Ferrarese forebears, that includes the italianita which he feels is his as much as it is that of any other fellow Ferrarese. We see this sense of "modernità nella continuità" assert itself in other ways too in the adherence to the liberal, patriotic tradition. We have seen how in Gellnerian terms the io narrante represents a kind of apex of individuality and who happens to represent the highest ideals of a united Italy. Fascism was the negation of all that. Cristina della Coletta points out that the noted historian, Luigi Salvatorelli referred to the Fascist period as "l'Anti-risorgimento", and this term neatly encapsulates our io narrante's stance as well. She goes into much greater detail on this topic and illustrates how the frequent references to Carducci in Il giardino for example allude nostalgically to an Italy unsullied by Fascism and its vulgar populism:

I segnali intertestuali e le icone letterarie riconducibili al tempo dell'histoire (1932-1944) hanno importanza storicodocumentaria poiché, nel seguire il processo involutivo che vide la capitolazione dell'ideologia liberale al fascismo, ne testimoniano anche la tenace resistenza, ergendosi ad emblema della ribellione al programma di politico-culturale fascista, ai valori e ai miti promulgati dal regime fondata sulla difesa dei principi dell'indipendenza e della libertà individuali, sugli ideali filosofico-etici della "verità" e della 


\begin{abstract}
"bellezza", la cultura del giardino si oppone alle strumentalizzazioni culturali del regime, ai suoi espedienti ideologici, e agli orrori dei campi di battaglia. (1998:138163)
\end{abstract}

We see how Bassani conforms in a myriad ways to the quintessential liberal ideology and its triumph in modernity, (as opposed to the Positivist incarnation of Fascism as Croce describes it), which excites Gellner's mind so and of which he was a champion. However, what makes Bassani so useful, is that in his novels - and one is only limiting oneself to two is that many of the forces of anti-liberalism, of the anti-Risorgimento, of anti-Empiricism are arraigned against the protagonists, to say nothing of his delicate treatment of love, as we have it in Il giardino, the evanescence of love and life itself, and the surrender to art and the ideal, when the real becomes untenable, as exemplified in Celestino's relationship to Micòl, which in turn is rendered untenable by the awareness of the impending doom awaiting Ferrara's Jews.

Della Coletta goes on to quote from Salvatorelli and Renzo de Felice:

La diserzione della monarchia nel momento in cui avrebbe potuto difendere le istituzioni liberali, sommata alla chiamata al potere di Mussolini nell'ottobre del 1922, all'appoggio incondizionato offertogli dopo il delitto Matteotti, e in seguito all'acquiescenza nei confronti della politica antisemita del regime, la rese complice di tutti "gli svolgimenti anticostituzionali, anti-liberali e antirisorgimentali del fascismo, e responsabile del rinnegamento dei principi su cui si era fondata la nuova Italia. (1998:138163) 
Furthermore, Bassani also can be seen in light of the tradition, if one wants to call it that, of Italian Jewish writing's rich panoply which includes as we know Svevo, Moravia, Ginzburg Carlo and Primo Levi and of course Bassani. It is in Bassani that the tragedy of the history of AntiSemitism in Italy has its most ironic twist, in that:

Leaping to the forefront of Fascism's supporters, Ferrara's Jewish land-owning elite stood at the opposite pole from Turin's intellectual opposition to Fascism.

The laws of October 1938, therefore, were a stunning blow to Ferrara's Jews. The coup de grace, undoubtedly, was the destruction of the Scuola Tedesca, and Ashkenazi synagogue in 1941. Thoroughly disillusioned, Ferrara's Jews felt utterly betrayed by a movement which they had wholeheartedly embraced and supported only a few years earlier. [...] Bassani plumbed the depths of betrayal and ostracism, the motor forces of his characteristic expression of nostalgia. [...] Professor Finzi-Contini symbolizes the spiritual universe beyond assimilation. (Pedatella, 1987:167174)

A further example of how a Gellnerian reading of Bassani is useful is when we look again at Language \& Solitude where Gellner says: "The individualism remains prominent and basic: the basic model is that of an individual facing his data and constructing a world from them in light of and under the guidance of principles which he finds within himself" (1998:15-16). Here Bassani's io narrante and Gellner dovetail perfectly. Bassani's io narrante: "[...] sifts out the impurities introduced into his experience by the prejudgements, the prejudices of his social milieu [...]" (Gellner, 1998:17). 
Synthesising Kant and Hume Gellner concludes that "Ordnung", human universality rather than cultural specificity is the key to a moral approach to the world. Again we see how this operates in Bassani. The io narrante seeks to find an "impartiality and a symmetry", (Gellner, 1998:17) ${ }^{5}$ to use Gellner's words, in a world and milieu where symmetry has been lost, where the moral and social are out of kilter with the principles of civil co-habitation and specifically in a society such as Ferrara of the 1930s, where the citizenry harbour claims of adhering to civilised norms, as long as those norms exclude homosexuals and Jews.

Gellner's observations relate to his investigation of the theory of knowledge and while he is sceptical of the notion that impartiality can really exist, what is pertinent in Bassani's portrayals is the blend of culturally specific values combined with a rationality as something to be aspired to. The io narrante does discriminate, and does not adhere to the moral relativism, Gellner's bête noir, caught as Bassani's protagonists are between Gellner's atomistic vs. organic view of the world.

\section{Further observations and area of investigation: Postmodernism, Gellner and Bassani}

Gellner is highly critical of Postmodernism, and sees it merely as an adjunct to, a derivation of, moral relativity. He says for example, opening the discussion widely into the realm of philosophy that:

$[\ldots]$ the arguments between the universalistic liberals and the romantic rightists is an argument about the very nature of man... we find ourselves in a remarkable situation in which

\footnotetext{
"So impartiality and symmetry, Ordnung, hence human universality rather than cultural specificity, is the basic message" (Gellner, 1998:17).
} 
the political stakes of philosophical visions are very great.

[...] Community is sung and praised by those who have lost

it. $(1998: 20-21)$

As mentioned, Gellner goes on to make the distinction between a "universalistic-atomistic" and a "romantic-organic" vision of the world. He sees these as the two great rivals of the modern era and attributes this polarity to the rise of nationalism. Gellner's observations thus also allude to a further decipherment of Bassani's text, namely that an individual brought up in the "universalistic-atomistic" tradition can only be in conflict with the "organic-romantic vision of the world, that implicitly excludes those elements that are not integral to a specific ethnically-based culture or view of the world. In the case of Bassani, we have our "universalistic-atomistic" individual having to live his life in a milieu that is essentially "organic-romantic", even though Fascism went to great lengths to promote itself as modern. Fascism can thus also be seen as the "romantic-organic" acquiring some of the traits and aspirations of being "universalistic-atomistic". Because it is ultimately incapable of pulling off this ruse, Fascism collapses under its own contradictions, not without leaving a tragic legacy. It is this legacy which Bassani has articulated again by using his protagonists as the vehicle for what one could term his "empirical poetic style".

Our character of course sees through the mendacity of Fascism and the supposed claims it makes on universalism, within a nationalist context. Or as Gellner would put it - the absolute is used as an idiom for perpetuating a specific tradition. In Bassani's case it is the absolutism of the state vs. the absolutism of his religion and his Enlightenment view of the world.

In this sense too, paradoxically, Bassani's protagonists reflect the Fascist state, caught as it is between claiming to be the continuation of 
ancient Rome, while being seeing itself at the forefront of modernity. (We know how much Fascism drew much of its visual rhetoric from the Futurists.) The parallels between the io narrante and the Fascist state itself lie in the "continuità nella modernità"; both the protagonist and his historical situation reflect each other, with the difference being that Jewishness is what lies at the foundation of the protagonist's sense of continuity, whereas for the Fascist state it is "romanità".

False consolation Gellner, would aver, is to be found in a Postmodernist view of the world. The question then arises, having read Bassani through Gellner's eyes, can a Postmodernist approach really help us to unlock and indeed amplify Bassani's "text"? The key to Gellner's critique of Postmodernism is that besides it being merely reliant on relativism, it is "a kind of hysteria of subjectivity" (Gellner, PPR 1992:29).

While Gellner has much to say about Postmodernism, and it is not the aim here to tackle Postmodernism per sé, what Gellner has to say is useful for our purposes:

Truth is elusive, polymorphous, inward, subjective... and perhaps a few further things as well. Straightforward it is not. My real concern is with relativism [author's italics]: the postmodernist movement, which is an ephemeral cultural fashion, is of interest as a living and contemporary specimen of relativism, which as such is of some importance and will remain with us for a long time. (PPR, 1992:24)

Neither Gellner nor Bassani are satisfied with cognitive relativism and any consequent paralysis that would ultimately lead to ethical indifference. Bassani's novels, and in particular the two under discussion, would seem to defy a postmodernist reading, were such an analysis to lead 
to the relinquishing of absolute notions of right and wrong. As Buchowsky points out:

Gellnerian rationalism shares with Religious
Fundamentalism the 'belief in the existence of a unique truth'
(PRR:84). Unlike religious dogmatic ideology, however, it
does not make exceptions for any concept. Rationalist
empirical method is symmetrically applied to every issue,
and the content of each belief should be rationally assessed.
The only absolute value is the formal principle of the
scrutinization of everything. Rationalist Fundamentalism
does not accept the relativistic idea that there can be many
truths and standards of rationality as can be determined by
'different life forms'. However, paradoxically, along with
relativism it does not permit the accessibility of ultimate
knowledge.[...] Postmodernist discernments can be valuable
in art and entertainment but not in substantial aspects of our
life. Serious knowledge is not subject to relativism, but the
trappings of our life are." (PRR:95) (2003:34) (13)

Expiation for the sins of colonialism, (if that is as Gellner suggests, the psychological basis of Postmodernism) has little to do with the ethical and physical dilemmas that Bassani's characters face. (One could of course build up an argument to draw parallels.) Like Gellner, Bassani's characters have to navigate the solitary road of truth, relying on what they observe and how that world is filtered into their consciousness. There's no "cosy habitat" to protect them from the state and society's ulterior motives and expediency.

If one were to counter the notion of the acquisition of "truth" as being an essentially solitary activity, we could soon find ourselves in the realm of relativity, with each individual living their own truth, as per Pirandello, 
for example and the precedent he set for much of modern thought. By contrast, and to contextualise briefly Bassani and Gellner, they do tend towards upholding a belief "that there is a unique truth", which is simply unattainable by any given society, indefinitely. Neither pretends to plumb the depths of existence beyond a certain point by claiming that truth is relative. But as for being an aid to reading a text we find Gellner can give us many useful pointers or markers on our way.

It thus behoves us to take to heart Gellner's idea that enlightenment rationalism upholds the idea that there is a unique truth, and while he denies that any society can ever possess it definitively, in Gli occhiali and in Il giardino we have protagonists that live this impasse, of two views of knowledge, the "atomistic" and the "organic".

\section{Bibliography}

Bassani, Giorgio

Bassani, Giorgio

Buchowski, Michal

Della Coletta, Cristina
1976 Il giardino dei Finzi-Contini, Milano: Arnoldo Mondadori.

1983 Gli occhiali d'oro, Milano: Arrnoldo Mondadori

2003 "The Social Condition of Knowledge: Gellner and the Postmodernist Menace" in Social Evolution and History, Summer 2003, Volume 2, Number 2: 34-54, Moscow: Uchitel Publishing House.

1998 La cultura del giardino: Miti e appropriazioni letterarie nel "Giardino dei Finzi-Contini”: $M L N$, Vol. 113, No. 1, Italian Issue (Jan., 1998:138-163). 
Baltimore: The Johns Hopkins University Press. http://www.jstor.org/stable/ 3251071

Heady, Patrick

Gellner, Ernest

Gellner, Ernest

Gellner, Ernest

Gellner, Ernest

Pedatella, R.A.

Pieri, Piero
2003 “Gellner's Ideal Kinship Language and the connection between Biological and Social Relatedness" in Social Evolution and History, Summer 2003, Volume 2, Number 2:75-87 Moscow: Uchitel Publishing House.

1959 Words and Things - An Examination of, (rev. and an Attack, on Linguistic Philosophy, 1979) London: Routledge \& Kegan Paul.

1992 Reason and Culture - The Historic Role of Rationality and Rationalism, Oxford: Blackwell.

1992 Postmodernism, Reason and Religion, London: Routledge.

1998 Language and Solitude - Wittgenstein, Malinowski and the Habsburg Dilemma Cambridge: C.U.P.

1987 "Thematic Sketches of Twentieth Century Italian Jewish Writers", Jewish Social Studies, Vol.49, No.2 (Spring, 1987:167174). Indiana University Press: http://www.jstor.org/stable/4467375

2006 "La passeggiata prima di cena", in Una Giornata di Studi per Giorgio Bassani, (eds. Dolfi Anna, \& Venturi, Gianni) Roma: Bulzoni Editore. 
Radcliff-Umstead,
Douglas

Renda, Marilena

Venturi, Gianni

\section{Further Reading}

Aragno, Piero

Chiappini, Alessandra \& Venturi, Gianni

Croce, Elena \& Foulke, 1963 Adrienne

1995
1985 "Bassani: The Motivation of Language" Italica, Vol. 62, No. 2. (Summer, 1985: 116-125). American Association of Teachers of Italian, http://www.jstor.org/ stable/478781.

2006 "Lo spazio vischioso" in Una Giornata di Studi per Giorgio Bassani, (eds. Dolfi Anna, \& Venturi, Gianni) Roma: Bulzoni Editore.

2006 "Dimenticare Euridice" in Ritorno al Giardino - Una Giornata di Studi per Giorgio Bassani, (eds. Dolfi Anna, \& Venturi, Gianni) Roma: Bulzoni Editore.

1986 "Fascismo e narrativa: una proposta di critica politico-ideologica (con qualche riscontro americano)" by Alberto Traldi, Italica, Vol. 63, No. 4, Perspectives on the Novecento (Winter): 411-412. American Association of Teachers of Italian.

Bassani e Ferrara - le intermittenze del cuore, Ferrara: Gabriele Corbo Editore, 1995.

"Notes on Italian Literature, 1960-63" The Hudson Review, Vol. 16, No. 3. (Autumn): 420-428. 
De Stefanis, Guisi Oddo

Dolfi, Anna

Frandini, Paola

Gillette, Aaron

Guiati, Andrea

Klopp, Charles D.

Lucente, Gregory L.

Prebys, Portia

Radcliff-Umstead, Douglas
1981 Bassani entro il cerchio delle sue mura, Ravenna: Longo Editore.

2003 Giorgio Bassani - Una scrittura della malinconia, Roma: Bulzoni Editore.

2004 Giorgio Bassani e il fantasma di Ferrara, Lecce: Manni.

2002 Racial Theories in Fascist Italy, London and New York: Routledge.

2001 L'Invenzione poetica - Ferrara e l'opera di Giorgio Bassani, Pesaro: Metauro Edizioni.

1974 "Some Considerations on Histories of the Italian Novel: Olga Lombardi's La narrativa italiana nelle crisi del Novecento", $M L N$, Vol. 89, No. 1, The Italian Issue: 115-123.

1984 "Scrivere o fare...o altro: Social Commitment and Ideologies of Representation in the Debates over Lampedusa's Il Gattopardo and Morante's La Storia" Italica, Vol. 61, No. 3. (Autumn, 1984): 220-251.

2002 Giorgio Bassani: bibliografia sulle opere e sulla vita, Firenze: Centro Editoriale Toscano.

1987 The Exile into Eternity - A Study of the Narrative writings of Giorgio Bassani, 
London, Mississauga: Associated Universities Press.

Marianne Shapiro

Schneider, Marilyn

Schneider, Marilyn
1972 "The Storie ferraresi of Giorgio Bassani", Italica, Vol. 49, No. 1: 30-48.

1986 Vengeance of the Victim - History and Symbol in Giorgio Bassani's Fiction, Minneapolis: University of Minnesota Press.

1974 "Mythical Dimensions of Micòl FinziContini”, Italica, Vol. 51, No. 1 (Spring, 1974): 43-67.

\section{Works by Ernest Gellner:}

Legitimation of Belief

Spectacles and Predicaments: Essays in Social Theory

Nations and Nationalism

Relativism in the Social Sciences

Culture Identity and Politics

Plough, Sword and Book

Postmodernism, Reason and Religion

Conditions of Liberty: Civil Society and its Rivals
1975 Cambridge: C.U.P.

1980 Cambridge: C.U.P.

1983 Oxford: Blackwell.

1980 Cambridge: C.U.P.

1985 Cambridge: C.U.P.

1988 London: Collins Harvill.

1992 London: Routledge.

1994 London: Hamish Hamilton. 

Nicolson.

\section{Works on Ernest Gellner:}

Hall, John A.

1989 "They Do Things Differently There, or, the Contribution of British Historical Sociology", The British Journal of Sociology, Vol. 40, No. 4: 544-564.

Hall, John A. \& Jarvie, I. 1996 (Eds)

The Social Philosophy of Ernest Gellner, Amsterdam, Atlanta: Rodopi.

Lessnoff, Michael

Ernest Gellner and Modernity, Cardiff: University of Wales Press.

Malesevic, Sinisa \& 2007

Haugaard, Mark, (Eds)

Ernest Gellner and Contemporary Social Thought, Cambridge: C.U.P.

O’Leary, Brendan

1997 "On the Nature of Nationalism: An Appraisal of Ernest Gellner's Writings on Nationalism", British Journal of Political Science, Vol. 27, No. 2: 191-222. 